\title{
Strategy for reduction of medical costs and growth of the healthcare industry after establishment of the national health insurance system in Japan: lessons for the Indonesian health care reform system -II-
}

\author{
Tokihiko Sawada, Hirohisa Kawahara
}

Kaikoukai Medical Foundation, Japan

\begin{abstract}
Abstrak
Jepang sudah sejak lama menggunakan asuransi kesehatan pemerintah yang meliputi seluruh populasi, dan difokuskan pada keseimbangan kemampuan pelayanan kesehatan dan kebutuhan pengurangan beban biaya kesehatan nasional. Hemodialisis merupakan layanan kesehatan yang di masa mendatang diharapkan menjadi besar di negara seperti Indonesia, yang memerlukan dukungan biaya yang besar dari sistem asuransi kesehatan nasional. Dalam laporan ini, yang merupakan lanjutan dari laporan sebelumnya, digambarkan bagaimana strategi pemerintah Jepang meminimalisir pengeluaran biaya kesehatan, terutama untuk hemodialisis.
\end{abstract}

\begin{abstract}
Japan has long operated a government-based health insurance system covering the entire population, and has been focusing on strategies for balancing viable national health care services with the need to minimize national health care expenditure. Hemodialysis (HD) is a representative form of medical treatment that is expected to expand in Indonesia in the near future, and which will require sustained financial support from the national health insurance system. In this report, consecutive to our previous one, we describe how the Japanese government has attempted to minimize medical expenditure in the past, focusing especially on HD.
\end{abstract}

Keywords: health care reform, medical cost, national health insurance pISSN: 0853-1773 • eISSN: 2252-8083 • http://dx.doi.org/10.13181/mji.v23i3.1003 • Med J Indones. 2014;23:182-4 Correspondence author: Tokihiko Sawada, tsawada@kaishou.or.jp

In our previous report, we described how Japan had focused on hemodialysis (HD) after the establishment of the government-based health insurance system (GBHI) in 1962, ${ }^{1}$ as we considered that the lessons learned from the Japanese experience would be pertinent for Indonesian society, which is establishing its own GBHI at a time of rapid growth of both the economy and the population.

Here we describe a strategy for control of medical expenditure, focusing especially on HD, and expansion of the healthcare industry, which could have a positive impact on the GBHI.

\section{Minimizing the costs of $\mathrm{HD}$}

The Japanese government has been trying to minimize the cost of HD in two main ways. One is control of the retail price of medical equipment. The other is to integrate some dialysis-related medical fees such as those for medical techniques, drugs, and instruments, into a single category to create an overall price for HD.

As described in our previous report, the cost of HD amounted to about US\$ 5,000 - 6,000/person/ month between 1970-1990, and 4,000/person/month thereafter. For example, in 2010, 298,252 patients were receiving HD in Japan, costing US\$ 14.3 billion/year. Since HD began to be covered by the GBHI in 1967, the payment system has been changed frequently in efforts to minimize expense. ${ }^{2}$ In 1967 , costs for medical techniques related to HD and items such as dialysers and tubes were paid on an individual basis, and the total cost was about US\$1,500/person/ month. With improvements in technology, including

Copyright@2014 Authors. This is an open access article distributed under the terms of the Creative Commons Attribution-NonCommercial-ShareAlike 4.0 International License (http://creativecommons.org/licenses/by-nc-sa/4.0/), which permits unrestricted non-commercial use, distribution, and reproduction in any medium, provided the original author and source are properly cited. 
dialysers, the cost of HD was about US\$ 5,400/ person/month in 1972. As described in the previous paper, ${ }^{1}$ the number of patients with HD increased rapidly thereafter, and the total cost of HD grew concomitantly. In 1978, the government decided to cover the cost of HD, including all techniques and materials, and set the amount at US\$ 4,800/person/ month. Later, however, in 1981, the government reverted to covering the cost of techniques and materials on an individual basis, amounting to US\$ 2,400 and $1,116 /$ person/month, respectively.

The cost of HD covers other factors, such as sterilization of materials, dialysis at night, water processing, and others items. All of these costs have been changed as a result of targeting by the government to minimize expense. Although initially these costs were covered on an individual basis, the various individual factors were categorized into a single section to minimize the total cost. Biochemical laboratory tests and roentgenograms were performed routinely in HD clinics for maintenance of patient health, and the costs of those tests were covered individually, whereas costs for routine tests were included under the category of HD in 1992. Anticoagulants such as heparin and nafamostat mesilate are indispensable for performing HD, and the cost of anticoagulants was integrated into the total in 1994. Anemia is the biggest complication of patients with ESRD, and development of recombinant erythropoietin (EPO) has dramatically improved the outcome of affected patients. EPO was introduced into Japan in 1990, and it was reported that about $85 \%$ of patients on HD were using EPO in 2004. The cost of EPO was integrated into the HD category in 2006.

\section{Changes in HD-related medical issues}

\section{Employment}

As described in our previous paper, establishment of a government-based health insurance system has allowed patients to visit hospitals and increased demand for medical treatment. The numbers of hospitals and clinics, including dental clinics, have increased steadily between 1960 and 2010 (Figure 1), ${ }^{3}$ and those offering HD facilities numbered about 3,700 in 2000 and 4,100 in 2010. The numbers of total patients, outpatients and inpatients increased steadily until 1990, and have remained steady thereafter (Figure 2). ${ }^{4}$ This trend has been reflected in the numbers of hospital beds (Figure 3$)^{5}$ and the numbers of doctors,

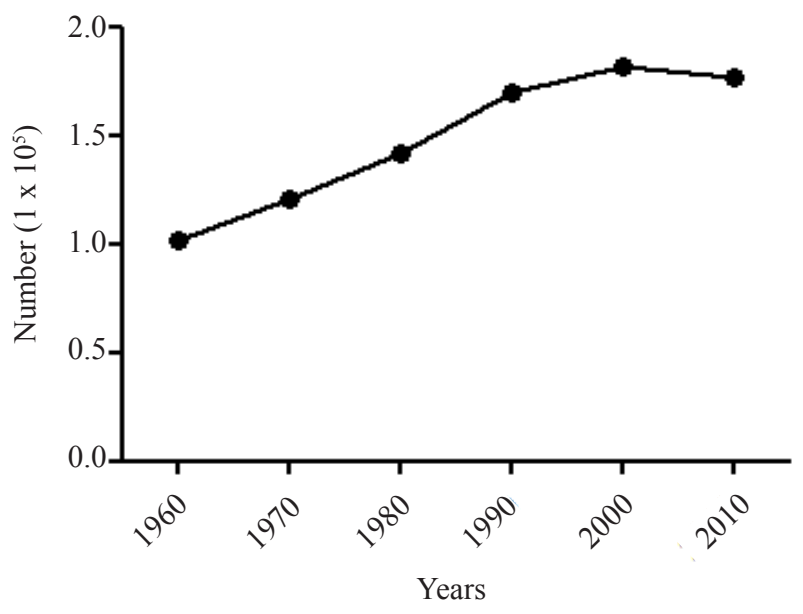

Figure 1. Number of hospitals and clinics

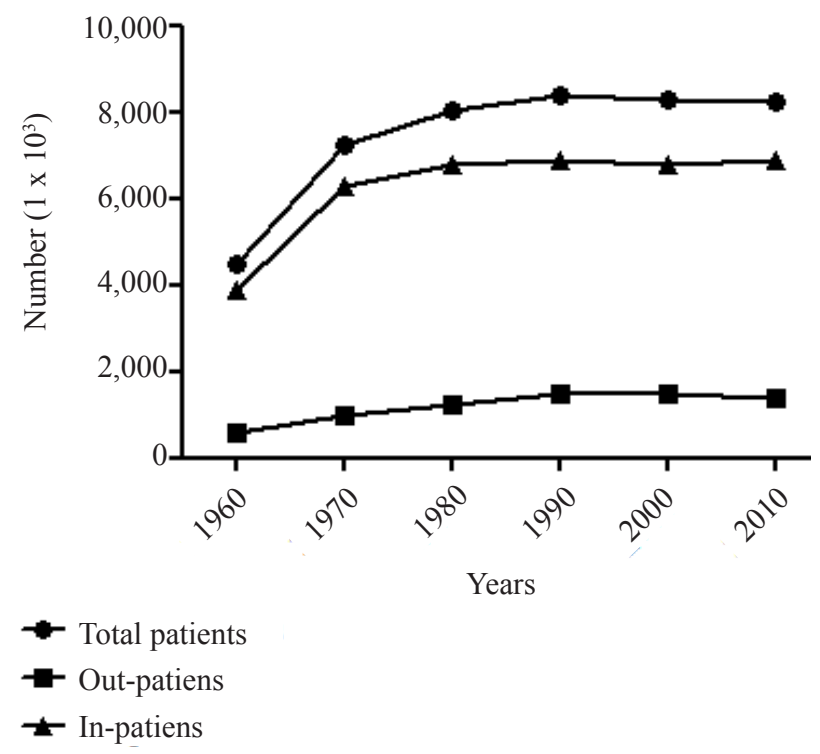

Figure 2. Number of patients

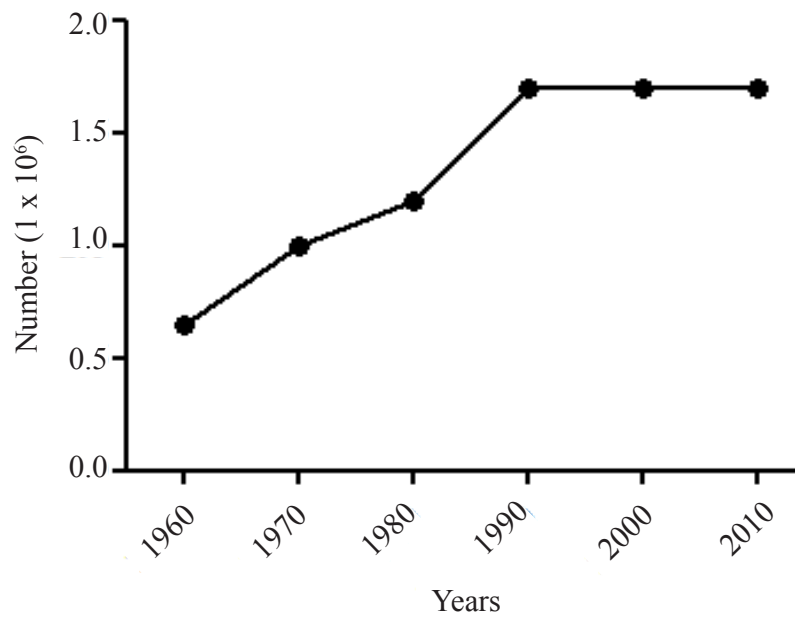

Figure 3. Number of hospital beds 
(A) Doctors, Dentists, Pharmacists

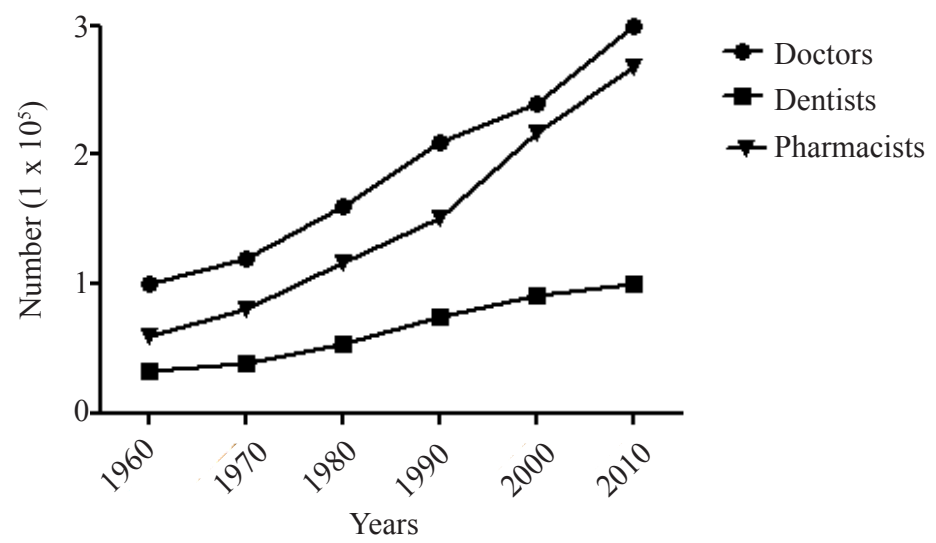

(B) Nurses

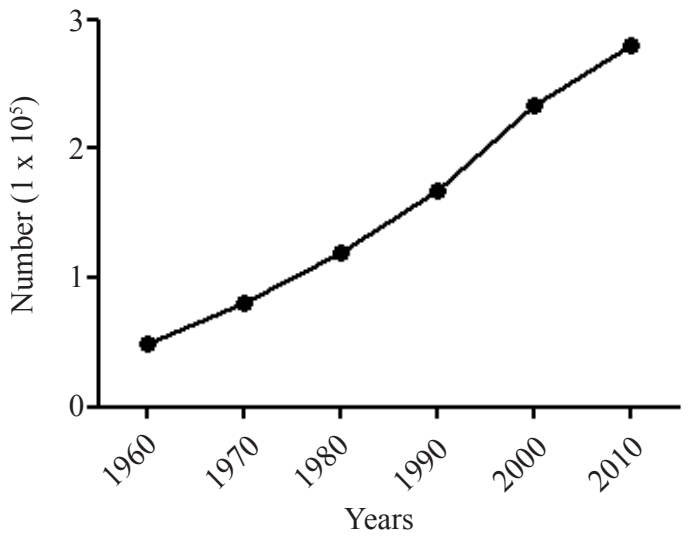

Figure 4. Numbers of doctors, dentists, pharmacists (A), and nurses (B)

dentists, and pharmacists (Figure 4A). In 1951, the qualification of assistant nurse was established in addition to licensed nurses, in response to the rapid increase in medical demand. Since then, the number of nurses has also increased with time (Figure 4B). In 2008, the total number of medical professionals, including physiotherapists, occupational therapists, clinical engineers, radiologists, laboratory medical technologists and others amounted to $540,000 .{ }^{6}$

Because in Japan medical costs are determined by the government and a free market does not operate, it is not easy to compare the situation with that in Indonesia. In 2011, medical costs in Japan amounted to US\$ 385 billion, accounting for $9.6 \%$ of GDP, and grossly, $10 \%$ of all medical expenses were for dialysis. Therefore, it is very important to minimize expenditure on dialysis. There are several strategies by which this could be achieved, the most important of which is prevention of ESRD. Currently, about $60 \%$ of patients who are started on dialysis have diabetes. Early detection and suitable control of metabolic diseases leading to ESRD, such as diabetes, hypertension, and hyperlipidemia, are crucial for prevention of ESRD. Other less expensive methods for management of ESRD, such as kidney transplantation and peritoneal dialysis, should be considered. Kidney transplantation, which is performed far less often in Indonesia than in Japan and other countries, is a promising avenue in this respect, and postoperative costs for maintaining ESRD patients are much lower than for dialysis.

Because medical costs and the health insurance system in Japan do not represent an open market economy, and are controlled by the government, annual medical expenses have grown every year, despite government attempts to counteract this. Medical expenses in Japan does not include private medical check-ups, childbirth, and vaccinations. On the other hand, the biotechnology industry in Japan, including pharmaceuticals and medical devices, is estimated to be worth about US\$ 80 billion annually. ${ }^{7}$ Growth of the medical healthcare industry would thus contribute to the Indonesian economy.

In conclusion, a health insurance system covering the entire population will improve the health condition of Indonesian citizens and contribute to uniting the country. Learning from Japanese experiences, Indonesia should avoid the negative aspects of a nationwide health insurance system, such as the huge financial burden, by minimizing medical expenses and stimulating the healthcare industry.

\section{REFERENCES}

1. Sawada T, Kawahara H. Cost of hemodialysis after coverage by national health insurance in Japan - A sharing experience with Indonesian reform system. Med J Indones. 2014;23(2):122-124.

2. Aichi Association for Dialysis. http://www.aichi-toseki.net/ file/12/hirasawa.pdf.

3. Minister of Health, Labor and Welfare, Japan. http://www. mhlw.go.jp/toukei/saikin/hw/iryosd/10/d1/shisetsu.pdf.

4. E-Stat. do?lid $=000001060228$

5. Minister of Health, Labor and Welfare, Japan. http://www. mhlw.go.jp/wp/hakusyo/kousei/07/d1/0101.pdf.

6. Minister of Health, Labor and Welfare, Japan. http:// www.mhlw.go.jp/wp/hakusyo/kousei/10-2/kousei-data/ PDF/22010209.pdf.

7. Mizuho Corporate Bank. http://www.mizuhobank.co.jp/ corporate/bizinfo/industry/sangyou/pdf/1021_03.pdf. 